\title{
(息)
}

Citation:

Morgan, $\mathrm{J}(2016)$ Corporation tax as a problem of MNC organisational circuits: The case for unitary taxation. British Journal of Politics and International Relations, 18 (2). 463 - 481. ISSN 1369-1481 DOI: https://doi.org/10.1177/1369148115623213

Link to Leeds Beckett Repository record:

https://eprints.leedsbeckett.ac.uk/id/eprint/2675/

Document Version:

Article (Accepted Version)

The aim of the Leeds Beckett Repository is to provide open access to our research, as required by funder policies and permitted by publishers and copyright law.

The Leeds Beckett repository holds a wide range of publications, each of which has been checked for copyright and the relevant embargo period has been applied by the Research Services team.

We operate on a standard take-down policy. If you are the author or publisher of an output and you would like it removed from the repository, please contact us and we will investigate on a case-by-case basis.

Each thesis in the repository has been cleared where necessary by the author for third party copyright. If you would like a thesis to be removed from the repository or believe there is an issue with copyright, please contact us on openaccess@leedsbeckett.ac.uk and we will investigate on a case-by-case basis. 


\section{Corporation tax as a problem of MNC organizational circuits: The case for unitary taxation}

\section{Jamie Morgan}

Abstract: The tax practices of multinational corporations have become a matter of significant public and political concern. The underlying issues are rooted in the capacity of MNCs to construct organizational circuits that enable taxes to be minimised in (ambiguously) legal ways. This is tax avoidance. Organizational circuits are one example of what Seabrooke and Wigan refer to as global wealth chains. The capacity to avoid tax arises because of the way MNCs are treated as a series of separate entities, subject to the arm's length principle. Unitary taxation based on formula apportionment provides a potential solution to the problems. This paper provides an overview of how tax avoidance is achieved, the problems that arise from this, and the benefits of unitary taxation as an alternative, and places this in the context of current policy trends. The purpose of the paper is to improve awareness amongst a politically literate academic readership of key issues for the main alternative to the current problematic situation.

\section{Tackling corporate tax avoidance: The case for unitary taxation}

The European Commission estimates tax avoidance and evasion within the European Union to be around $€ 1$ trillion per annum (EC, 2012, p. 2). The UK's budget deficit for the financial year 2013-2014 was approximately $£ 108$ billion and public sector net debt was $£ 1.4$ trillion. It is within this context of chronic public debt (see Thompson, 2013; Hay, 2013) that corporations are able to pay effective tax rates that are many times smaller than the headline rate of corporation tax. Any business able to locate separate entities in different tax jurisdictions is able to legally limit the tax that it pays in ways that are not open to other firms or the ordinary citizen. This legal minimisation is tax avoidance (evasion is categorised as illegal tax behaviour, the difference is elaborated later). As any reader of the media will know, tax avoidance has become a particular problem focused on multinational corporations (MNCs). The following paper explores, with a focus on MNCs, how tax minimisation is achieved. This is based on the capacity to create organizational circuits through which MNCs can advantageously shift sales, revenue and profit. These organizational circuits serve to illustrate the significance of global wealth chains (GWC, Seabrooke and Wigan, 2014) as an important adjunct to the concept of global value chains. Much of the capacity to engage in tax avoidance is a consequence of a longstanding structural flaw in the international tax system. Specifically, reporting on the basis of separate entity status and the arm's length principle. The problems that arise provide the basis of the case for unitary taxation of the MNC as a single organization.

Corporation tax is an important subject matter that too often is relegated to discussion among only the legally trained and technically proficient. The purpose of this paper is to improve awareness amongst a politically literate readership of key issues for the main policy alternative. The problem of tax is necessarily political. In order for unitary taxation to become policy there must be momentum for its adoption. Unitary taxation involves fundamental change to the opportunities available to corporations. It raises both technical issues of design 
and strategic issues of implementation. However, the most significant hurdles to its adoption are ignorance regarding its potential and resistance based on power and embedded interests. In a democracy and within international society, the former augments the latter.

The paper is set out in several sections. A first section sets out the key concepts of separate entity status and the arm's length principle, which shape the current potential for tax avoidance based on transfer pricing. The second section provides a generic illustration of how tax avoidance is achieved. The third section sets out the current problems of tax avoidance, and this leads to a fourth section, which sets out unitary taxation. Unitary taxation creates an initial challenge in terms of achieving agreement to establish rules of application. However, the issues arising are not significantly different than confront any constructive attempt to critically contest the status quo. Neoliberalism began as an institutional projectbuilding exercise based on knowledge sharing and policy transfer, and any policy change that contests its current form must also begin in the same way (e.g. Brenner et al, 2010). A final section explores some of the current policy trends likely to influence the adoption of unitary taxation.

\section{The emergence of a structural flaw: Separate entity status and the arm's length principle}

As specialists at the Tax Justice Network have consistently argued, the problems of taxation associated with MNCs have a root cause in a 'deep structural flaw' (Picciotto, 2014, 2012; CRC, 2014). The fundamentals of the rules governing taxation for MNCs date back to the 1920s. The rules are ad hoc, based on many bilateral agreements rather than a single coherent, binding and governing multilateral agreement. However, they are also in many respects common based on a series of developments of model treaties, notably from the OECD (the 1992 model convention is now in its $9^{\text {th }}$ iteration, OECD, 2014). Agreements share key features. Since an MNC is able to incorporate legally distinct entities and locate these in any accommodating jurisdiction, tax agreements, arising law and practice have developed which take this separate entity status as given. The primary focus has been on taxing each entity based on its reporting of income in that jurisdiction. Issues of the links between the entities follow because of this separation.

Transformations throughout the later twentieth century have served to augment the problems. Communication technology has radically transformed the potential for the geographical separation of administration from other aspects of business activity. Also, as globalization has advanced there have been changes to the structure of production and administration. These include long supply chains and complex systems of importation for final assembly. Changes create great scope for differentiations along chains of activity and this has normalised (in the sense they are common and thus expected) the existence of complex interconnections of entities (Clausing, 2006). Concomitantly, there has been a qualitative shift in regard of the goods and services produced - tied more to branding, intellectual property rights and patents - and how they are sold (via the Web). There can be many types of separation and this can conceal (within and because of the normalisation of complex interconnections) that some forms of separation can serve non-economic ends, in the sense of having little to do with actual production and distribution of goods and services. ${ }^{i}$ Not only is it relatively 
easy to create separate entities, law and regulation has done little to impede the capacity to do so, and in many places has actively encouraged the practice. As Palan (2002) sets out, many states have "commercialised" their sovereignty within a global political economy.

A further aspect of tax agreements arises because of the issue of links between entities. An MNC is a recognizable organization. The term is not senseless. However, given that it can be structured as a set of legally separate entities, one can equally say that it does not exist in law (Picciotto, 1992). Yet there is a whole subject to influence and control. The firm or organization engages in activity between its parts. Economic theory of the firm claims this to be efficient in so far as intra-firm activity reduces transaction costs (Coase, 1988). However, intra-firm activity creates the potential for the actual values of transactions to be attributed to different parts of the firm to concentrate the reporting of income in particular places. This has tax consequences. The majority of income may be reported in one tax jurisdiction to the detriment of another, for example, country A rather than B. Country B may then respond by contesting the reporting and imposing its own tax rules, creating the potential for double taxation of the same income. Relatedly, the majority of income may be reported in one tax jurisdiction rather than another in order to realise a tax advantage (reducing the total tax the firm pays).

A means was then required to assess how values for transactions are distributed between the entities, which could then be incorporated into agreements between tax jurisdictions (typically countries). In response a family of tests has been developed based on the 'arm's length' principle (now stated as Article 9 of the OECD model convention). ${ }^{i i}$ The principle looks at the transactions between entities that form part of an organization to assess whether they have price determination characteristics that one would expect based on a market situation. There is an immediate contradiction here. If intra-firm transactions are intended to reduce transaction costs because of the internal nature of the relation, but the test of those transactions are based on a principle that the values ought to reflect distanced market relations, then the very form of the principle is incoherent from the point of view of theory of the firm. iii

Thereafter, the arm's length principle has proved both conceptually and practically problematic. The aim of the arm's length principle is to assess transactions in comparison to the value that would be created by a market price. Real markets tend to be imperfect so the concept of an abstract market price, implying perfect competition, is not easily invoked. Moreover, a great deal of the business activity in real economies occurs within MNCs and through their supply chains (more than $60 \%$ of world trade according to the OECD, 2002/2008). Many transactions occur between oligopolistic MNCs, and/or involve the apportionment of uniquely defined values based on royalties for licensed uses. Unique values in general create the problem of what is a value and how it is derived - particular problems for intellectual property, intangible assets and the digital economy. So, not only is it typically difficult to apply a practical test of what a competitive market price would have been in a given case, the very form of modern economies seem to be developing in ways that exceed the capacity of the arm's length principle to be applied effectively (UK HMRC, 2015a). There is then great scope for MNCs to engage in forms of transfer pricing. Transfer pricing simply means the allocation of values or prices between its entities in a chain of 
activity. It is not necessarily manipulative in an adverse sense but clearly creates the opportunity for such manipulation.

Since it can be difficult to apply the arm's length principle it can be difficult to dispute and "correct" where income is reported for tax purposes (see Kobetsky, 2011: pp. 394-395). The problems are such that in 2008 Edward Kleinbard, then chief of staff of the US Congress Joint Committee on Taxation characterised the situation as dysfunctional, stating 'transfer pricing enforcement is dead [...] Despite everyone's efforts we're not collecting tax. It's a global problem' (Sullivan, 2008: p. 1; also Murphy, 2014, Picciotto, 2011).

\section{Organizational circuits, global wealth chains, and tax focused coordination}

The arm's length issue is just one of the problems arising for tax law. The basic problem is that MNCs are capable of particular forms of coordination, and separate entity status creates incentives for coordination to become focused on tax. MNCs are provided with incentives to develop strategies that seek to minimise taxation through shifting where sales, revenues and profits are reported. New entities are created in particular localities and functions are hived off to those entities to create organizational circuits. Organizational circuit is intended as a convenient descriptive term for the connectivity of otherwise separate entities. Whatever functions some of the independent parts have, the whole is also configured to enable the minimisation of tax. The particular forms the circuit may take serve to illustrate Seabrooke and Wigan's (2014) recent call to develop an understanding of global wealth chains (GWC) as an adjunct to the more common emphasis on global value chains. Many others have set out the ways in which the post-Fordist period has involved the development of a variegated, unevenly developing neoliberalism (e.g. Peck, 2013). Within this development one key feature to emerge has been a disaggregation of firm activity, spreading out across territories and involving different types of ownership and control, creating a global value chain (Gereffi, et al, 2005). Much of the focus of work on global value chains has explored the political economy of production. This tends to underemphasise the movements in finance, law and arising strategies and practices that are also developed. That is, a global wealth chain or:

"[T]he linked forms of capital seeking to avoid accountability during processes of pecuniary wealth creation. By accountability we mean fiscal claims, legal obligations, or regulatory oversight... wealth chains are articulated not only through cartographic and sovereign spaces but also within financial products... Wealth chains hide, obscure and relocate wealth to the extent that they break loose from the location of value creation and heighten inequality." (Seabrooke and Wigan, 2014: p. 257)

As Seabrooke and Wigan note, these are the 'yin to the yang of value chains' (ibid). Value chains tend to focus on innovation and reorganization of production, but MNCs equally seek ways to reorganize and "innovate" to minimise taxes and hide capital. There are many strategies used to minimise tax and the specifics of these are constantly shifting (Kleinbard, 2013). However, there are several common features one often finds in strategies using organizational circuits. The MNC can: 
1. Create separate entity (A) in a nodal (meaning of central importance to a network) location. This entity will be the one to which the majority of income, revenue, and profits are ultimately channelled for reporting. A key characteristic of this location is that it applies little or no corporation tax. Historically such locations have also required minimal accounts be provided to the jurisdiction's tax authority (the firm will of course produce accounts for its own purposes). These locations have also typically resisted information exchange with other tax authorities (though this is changing, see later). Entity (A) will then be located in what is commonly termed a tax haven (see Shaxson, 2011; Zorome, 2007).

2. Establish separate entity (B) in a locality that has significant tax advantages relative to other locations. The MNC does so based on an analysis of the relative characteristics of the multiple locations in which it currently does business, and any related locality in which it could also incorporate (based, for example, on the need to be within a given administrative or trade bloc). This advantage may be either a lower level of corporation tax or an amenable government willing to negotiate a specific tax arrangement with the MNC.iv Crucially (in this initial generic example), this locality must also allow reporting in the location where $(\mathrm{A})$ has been created, providing a channel to (A).

3. Organize the different components in the rest of the production and administration process or the supply chain as entities (C) (D) (E) etc. The MNC then identifies some key mechanism through which the majority of values, sales, or revenue can be channelled to (B):

- Simple transfer pricing. For example, the value of a good or service can be minimised within entity $(C)$ but its added value when ownership is transferred (as a transaction) to (B) can be maximised. This minimises tax liability in the higher tax regime of the locality of entity (C). The process can be repeated for (D) (E) etc in relation to (B) or be applied along a chain of (D) (E) (F) etc to get to (B). This is a typical strategy with commodities, such as metals.

- Sales completion. This involves differentiating between making sales and completing sales. Entity (C) is designated as a place where sales activity may occur but not where the final sale is completed. Sales are completed in (B) or in another entity in the same locality as (B) and then channelled to (B). Again, one can repeat for entities (D) (E) etc. This enables the concentration of the reporting of sales and hence of revenue in (B) where tax is minimised. This is a typical strategy for web-based sales.

- Use of copyright, branding, trademarks or patented items. Entities (C) (D) (E) etc trade under the name of a single organization and each contracts to (B) under a licence to operate or pays some significant proportion of the value of transactions as a fee to (B), which licences the use of the name and any related paraphernalia. This is essentially a form of transfer pricing. The fee can be adjusted such that (C) (D) (E) report any given revenue for tax purposes, ranging from a small profit to breaking-even or a reported loss. ${ }^{\mathrm{v}}$ Variations of this strategy can be used by many different kinds of MNC. For example, a manufacturer can differentiate its factories 
from a parent company with which they must contract; whilst a food and beverage chain may apply fees to its multiple outlets for the use of the trading name and branded products.

4. Entity (B) then channels some significant proportion of its concentrated income to entity (A) where little or no corporation tax is paid on any profit reported there. The tax authority of the locality of entity (B) may be satisfied based on its small proportion of the concentrated revenue. It may also benefit from real investment and employment from the MNC in addition to its role in facilitating the activity of (B). The channelling from (B) to (A) may be expedited in a variety of ways. For example, (A) may hold the copyrights, trademarks etc that are licensed to (B), who in turn licences all other entities. Alternatively (A) may provide (B) with loans and so (B) pays interest to $(A)$ and the interest effectively transfers the profits from (B) to (A). This principle can then be extended. Rather than fund dividend payments to shareholders through the repatriation of profits, which then become subject to taxation, the MNC can retain its capital in offshore entities and fund payments through bonds.

Clearly, there is great scope for variation in regard of these common features. The actual form may involve multiple (B)s or no (B) at all, if one can report directly to (A). It may involve no (A) in the sense of a recognized tax haven, simply a (B) to minimise tax. The numbers and purposes of (D) (E) etc may be many and create a bewildering web of apparent purposes and interlocking ownerships. However, the emergent point is simple. Whatever else some of the individual entities also do, the circuit is directed at the exploitation of the opportunity to minimise tax. There is a global wealth chain effect.

The technical term for the phenomenon of exploiting organizational circuits to reduce real taxation is base erosion and profit shifting (BEPS). Base erosion refers to the reduction in the total revenues that ought otherwise to be reported for tax purposes (the tax base). Profit shifting facilitates a divergence between headline rates of taxation and real or effective rates. The OECD states the BEPS problem as:

Over time, the current rules have also revealed weaknesses that create opportunities for BEPS. BEPS relates chiefly to instances where the interaction of different tax rules leads to double non-taxation or less than single taxation. It also relates to arrangements that achieve no or low taxation by shifting profits away from the jurisdictions where the activities creating those profits take place. No or low taxation is not per se a cause of concern, but it becomes so when it is associated with practices that artificially segregate taxable income from the activities that generate it. In other words, what creates tax policy concerns is that, due to gaps in the interaction of different tax systems, and in some cases because of the application of bilateral tax treaties, income from cross-border activities may go untaxed anywhere, or be only unduly lowly taxed. (OECD, 2013: p. 10)

Note that the OECD focuses the problem on the existence of disjunctions in tax treaties and systems. The development of organizational circuits has meant that 
the original chief concern with double-taxation has today become a recognized problem of radical reduction in tax payments and, in the extreme, double nontaxation (Kleinbard, 2011). This has acquired its own language of legitimacy and distinctions. The erstwhile taxpayer refers to their conduct as tax planning for tax efficiency. The tax authorities distinguish between legal tax avoidance and illegal tax evasion.

Note the terms avoidance and tax haven are contextual. One must use each advisedly. Avoidance may be legal but it can also involve degrees of 'risk', since the strategy may be open to challenge because of how it is positioned. The very existence of the arm's length principle means that some aspects of a strategy could be contested. With this in mind senior advisor to the Tax Justice Network, David Quentin, makes the case that avoidance blends into evasion along a continuum, but in a clearly discernible way based on the intent and awareness of the client and tax advisor (Quentin, 2014). The intent is to 'mine risk' or knowingly deprive the tax authority of tax that could be paid. However, the organization is still using and relying on the law. There is also, what Sharman (2010) refers to as 'calculated ambiguity'. The very nature of the law enables an organization to be two things at once (loss making and profitable). Concomitantly, whilst there is a common sense reference point for the term tax haven, all countries can be tax havens in relation to some other (see Picciotto, 1992). Moreover, use of the term can give the impression that it is only a small number of localities that are problematic. However, highly visible sites such as the Cayman Islands are merely destinations and many other sites play roles in flows of capital, not least the world's main financial centres (see Palan et al 2010).

\section{The consequences of tax-focused coordination}

The existence of separate entity status and a reliance on procedures such as the arm's length principle mean that the opportunity to create and exploit organizational circuits to achieve tax avoidance persists within a process. There is a context issue here where the structural flaw has, so far, limited the way in which the problem of avoidance is addressed.

Once tax law is based on separate entity status then a process is set in motion. The individual state is forced to respond to the potential for tax leakages by seeking to address the specifics of tax strategies, and must do so based on agreements with other states. Tax law becomes a proliferation of detailed responses to tax planning and of numbers of tax treaties with different states. There are, for example, currently more than 3,000 double taxation treaties in existence. Complexity arises because of the need to substantiate separate entity status and because of the need for information disclosure regarding the transactions between entities in different tax localities.

States, of course, are not innocent in this process. Once the system is structured around the separation of entities, states have motivations to compete for tax revenues, creating the potential for each to adjust their tax law in order to attract not only economic activity but also the reporting of revenues and profits. MNCs respond by 'treaty shopping', creating a form of arbitrage. The problem is further compounded by some states and localities opting for an extreme form of specialisation, becoming destinations commonly recognized as tax havens, but 
within a broader process of commercialization of sovereignty (Palan, 2002), which is itself a process within the changing architecture of neoliberalism (Brenner et al, 2010). It is important also to note that MNCs may not simply be opportunistic. They and the accountancy and consultancy firms they employ may also seek to shape the law and can be active agents of its administration (Sikka and Wilmott, 2010, 2013; Sikka, 2015). They are part of the process.

For example, the OECD is the major source of expertise, regulatory proposals and mechanisms for international tax law. International tax law is highly specialised and so the OECD tends to draw its personnel from a limited pool, essentially dominated by the major accountancy and consultancy MNCs. Most countries have developed local "generally accepted accounting principles" (GAAP), which are included in relevant statutes. It is the task of the International Accounting Standards Board (IASB) to harmonise these local GAAPs through its International Financial Reporting Standards (IFRS) Foundation. The Foundation is dependent on the same limited pool of expertise as the OECD. There is then a permanent problem of group-think based on expertise, as well as the potential for conflicts of interest and policy capture.

One can of course overstate the point here (see Eccleston et al 2015; Woodward, 2004). Competitive complexity does not simply result in a system that always and everywhere promotes tax avoidance. There are also countertendencies. States must respond to public pressure and also have a basic interest in maintaining their tax base. States are neither unitary nor necessarily the product of single sets of interests. The well-publicised "Double Irish", "Dutch Sandwich" and the recently exposed tax practices in Luxembourg are all based on variations of the organizational circuit set out in the previous section. A US Senate committee report in 2013 sets out the ways in which Apple allegedly used a series of entities focused on Ireland to minimise tax (Levin, 2013).vi Under pressure from the US government the Irish government has stated that it will not facilitate some forms of tax avoidance. Quite what that will mean is not yet clear in 2015. One of the controversial aspects of activity in Ireland has been the negotiation of confidential tax arrangements with MNCs by the state. The existence of these kinds of arrangements can constitute "selective advantage" and this violates EU law regarding free and fair competition. The EU has pursued numerous cases, for example, an arrangement between Starbucks and the Netherlands and Fiat and Luxembourg (EC, 2014; Barker and Houlder, 2014). vii

Final rulings on many of these cases have yet to be made, including Apple in Ireland, and the EC Competition Commissioner, Margrethe Vestager, recently noted that delays have been partly due to lack of cooperation from the relevant countries (Waterfield, 2015). More broadly, structure as context also matters for the general tendency (see EC, 2015: pp. 15-16 for the limits on the authority of the competition commissioner). Institutions limit the scope of any constructive countertendency that addresses tax avoidance. The OECD approach to BEPS identifies the issue as one of disjunctions in tax treaties and systems. The focus on given cases of alleged avoidance invites a case-by-case approach and selecting cases is not simple, since there are many millions of transactions between MNCs and there are MNCs active in many states. So, there is an issue of complexity in terms of the sheer number of possible transaction pricing problems and selective advantage agreements. Furthermore, a case-by-case approach tends to orient on more visible cases and necessarily entails dispute for each case. As Ms Vestager 
also recently noted "We cannot do every case in the world, but we can find cases that we think are deeply problematic", (Waterfield, 2015). A case-by-case approach requires investigation, information gathering, and perhaps lengthy litigation. The process is resource intensive. One may close loopholes and some tax avoidance may cease. Equally, the form may mutate. It may do so because the existence of separate entity status and a reliance on procedures such as the arm's length principle mean that the opportunity to create and exploit organizational circuits persists.

The point to emphasise is that it is the perpetuation of the deep structural flaw constituted by separate entity status that is at the heart of the problem (again see Picciotto, 2011). The system is one that is fundamentally distorted. It creates perverse incentives and can also produce harmful net outcomes. If coordination by MNCs is focused around tax planning as a focus of "efficiency" then decisionmaking may not reflect the degree to which the $\mathrm{MNC}$ is actually rooted in business activity in real economies in particular localities. The organization is able to benefit from Sharman's calculated ambiguity and a global wealth chain effect may result. If so, a kind of low-commitment capitalism emerges. ${ }^{\text {viii }}$ The MNC minimises its footprint and socio-economic contribution. Individual states then experience net losses of potential tax revenue, and because of the existence of tax havens and competition between states, this becomes a net loss to all states. National firms and any firm that chooses to be more responsible are put at a competitive disadvantage, and so the very system militates against any single national firm or MNC choosing to act more responsibly. When this becomes visible it has two further effects. First, it corrodes the general legitimacy of taxation, and this may result in conformity to the same types of behaviours. The socio-economic context becomes one pervaded by: if corporations don't pay their taxes why should I? This encourages a grey economy as well as populist backlashes against particular firms, whilst the general problem persists. Second, revenue losses undermine the capacity of the state to fund public services, and address problems of the business cycle through fiscal policy without creating further debt. This has been particularly noticeable during the Great Recession that followed the Global Financial Crisis. ${ }^{\text {x }}$

As noted in the introduction, there are many eye-catching statistics one might call attention to here. ${ }^{x}$ Furthermore, many prominent cases have been reported in recent years. In 2012 the UK House of Commons Public Accounts Committee called Google, Amazon and Starbucks as witnesses in a broader investigation into corporate taxation (HCCCPA, 2012). A follow up report focusing particularly on Google highlighted that between 2006 and 2011 the firm generated revenue from the UK of US $\$ 18$ billion whilst paying the equivalent of US\$16 million in corporation tax over the same period (HCCCPA, 2013: p. 15). According to Zucman (2014) Google's combined effective tax rate on profits outside the US (not just the UK) has varied over the last few years from $2 \%$ to $8 \%$. The subsequent popular backlash saw Google pay $£ 20$ million in UK corporation tax in 2013-14 (Starbucks also notably committed itself to paying $£ 20$ million). The payment, however, was on sales generated by UK clients of $£ 3.4$ billion; the effective tax rate that follows is ambiguous and may be as low as 1\% (Duke, 2014). The sudden shift under public scrutiny to greater tax payments serves to reinforce the perception that for MNCs such payments are arbitrary. This makes addressing a state's tax gap more difficult. The tax gap is the difference between what the tax 
authority projects it should collect in revenues within the tax year and what it is actually able to collect - the gap is a residual deriving from a grey economy, lost corporation tax, evasion etc. ${ }^{\mathrm{xi}}$ The last estimate in the UK by HMRC was for the financial year 2012-13, and put the tax gap at $£ 34$ billion (Aldrick, 2014a). Independent calculations using a broader measure of forms of tax avoidance produce higher estimates that can be double this figure (see Sikka and Willmott, 2013). Collection based on these figures would reduce the potential budget deficit and this is something all UK political parties now publically acknowledge.

The system of MNC taxation is distorted and these distortions have real consequences. They feed into a broader economic and social context. Public outrage is not created because MNCs break the law, but rather because they do not need to break the law in order to pay little or no tax. Pointedly they can choose to do so. This does, however, have further consequences for firms. It can create serious "reputational" damage for the individual firm and for business in general. This is also a general issue of the loss of trust (see Colledge et al 2014). This loss is reflected in the Institute for Business Ethics annual Ipsos/MORI survey of public attitudes towards business. The survey identifies tax avoidance as the most important issue that ought to be addressed by business (IBE, 2013: p. 2).

\section{Unitary taxation as a solution}

If the root cause of the problems is a deep structural flaw then the ideal solution is to address the flaw. This implies agreement to create universal, coherent and binding international tax law that is not based on separate entity status. This means treating the entire MNC as a single entity for tax purposes. That entity produces one set of master accounts, and thus one ultimate income and profit statement. The accounts are reported to a designated tax authority. A proportion of the profit is then allocated to individual states based on some universally agreed formula. The formula is constructed to represent real economic activity or presence in given localities. The formula typically includes measures of assets, employment and sales. It includes these measures since each may be represented to different degrees in different localities. Once the profit is apportioned between relevant states then the sum allocated becomes subject to corporation tax in that locality.

The approach is termed unitary taxation based on formula apportionment (see Picciotto, 2014; Kobetsky, 2011). In its ideal form it renders manipulative transfer pricing redundant. It removes the incentive to shift nominal operations into different jurisdictions, since there is no immediate advantage to doing so. Reporting strategies resulting in profit shifting would not affect actual apportionment, since unitary taxation is based on a common standardised measure. Firms may still choose to shift their real investment and economic activity, but would no longer have an incentive to create organizational circuits that simply shift where reporting occurs. As a result, firm decision-making would be focused more on economic efficiency than on a distorted sense of tax efficiency. This in turn would provide one avenue through which low-commitment capitalism might be addressed. Concomitantly the pressures on states to accommodate MNCs would qualitatively alter. There might still be the potential for tax competition in order to attract investment and employment, but there would be no pressure to tacitly facilitate tax avoidance in ways that create net 
losses to all states. The consequences of double non-taxation would also be obviated. For example, the practice of accumulating funds in tax havens, which the MNC then resists repatriating, would no longer have an organizational basis. Tax havens would thus begin to whither since one of their functions would be curtailed.

Standardisation would mean that the basis of treaty shopping would dissolve. As such, the dynamics of the current system in which MNCs play off states against each other would be altered. This would be a structural transformation. It would transcend the problems of the case-by-case loophole approach. The loophole approach tends to focus on particular companies and specific behaviours. Since a separate entity system continues to foster the opportunity for tax avoidance it creates the permanent potential for more cases and for continued corrosion of the general legitimacy of taxation, as well as problems of loss of trust that extend further than the activity of the particular corporation. A unitary approach has the advantage of reducing the specific and personalised nature of critique of corporations and the generalised impacts this creates.

A unitary approach affects the individual corporation but does so through the generalised impact on the structural dynamics of the tax system. It contributes to a recovery of sovereignty for the state and it changes the context of dialogue between corporations and critics. This is important because the current terms of dialogue are an impediment to constructive change. Any reading of the transcripts of UK and US government hearings on the subject makes this clear. Particular corporations are called as witnesses regarding tax avoidance and come with prepared statements and legal representation. An impasse typically results. Wellintentioned interlocutors engage in moralising, which also raises their media profile. Criticised corporations tend to fall back on the claim that they pay all legally required taxes. For example, Eric Schmidt executive chairman of Google stated in response to public criticism of Google's tax behaviour in the UK: "It is not up to the taxee to say how much tax to pay. Figure out what taxes you want to charge us and we will pay them. The fact of the matter is: what we are doing is legal," (Arlidge and Ungoed-Thomas, 2013).xii

This variety of reply is limited, and one that corporations often make. It is limited because tax avoidance is by definition legal. The reply is thus at a tangent to the concerns that provoke critique from politicians and the public. Tax practices based on organizational circuits are not simply following the law. They involve a process of shaping organizational activity to make use of the law. Tax avoidance is intentional activity. The MNC is not a passive recipient of a tax bill based on its economic activity. The MNC makes choices and these are reflected in different inflections to general legal fallback statements. There is a significant difference between the statement "we paid all legally required taxes" and "we structured our practices to minimise the taxes we paid". In the former one is following the law in a neutral sense and the implication is that the law had resulted in a determining and universal practice and outcome (the MNC is a passive recipient). In the latter, following the law becomes leading the law to places one can take it in order to exploit a potential. This latter sense begins from an adversarial relation between the corporation, the law, the polity and the public. It tacitly assumes that the default position of the corporation is to pay no tax using the law as a medium for this, since this is what one would do if not prevented (see Morgan, 2011). This is a position entirely at odds with contemporary business tropes: good governance, 
corporate social responsibility and corporate citizenship. Yet it is intrinsic to a legalistic response to issues of tax avoidance. It thus stands at odds with many of the claims the same corporations may make in other contexts.

The point to emphasise is that a unitary approach to corporation tax removes the basis through which contradiction arises. Unitary taxation can be part of a credible approach to restoring trust. It places corporate activity in a different context. It provides an institutional basis that removes some opportunities for practices that undermine ethical conduct. The impasse between moralising and legalism is thus potentially transcended. As such, unitary taxation provides a genuine basis for ethical conduct to play a more consistent role in corporate decision-making and thus in economic activity.

To be clear, however, unitary taxation does not guarantee that ethics will play such a role. It merely creates a more conducive environment because some forms of behaviour are denied to the firm (see Lawson, 2015). There is still a difference between denying an avenue for some forms of behaviour and changing the perspective of firms in regard of their behaviour. Concomitantly, it remains the case that there is a significant difference between a tax system in which compliance must be compelled and one in which cooperation is given, and this also applies to a unitary system. MNCs may still seek to subvert the system. The OECD recognizes that voluntary compliance is a cornerstone of effective taxation. This is clearly stated in its Principles of Good Tax Administration (OECD, 2001). The implication is that the socialisation of firms and the creation of constructive cultures matters. This is something that new research in economics and organizations increasingly recognizes for tax issues. Until recently a rational actor model dominated theory and research (based on Allingham and Sandmo, 1972). However, there is now a growing focus on reconceptualising tax-related behaviour and exploring different ways to socialise or incentivise compliance. This work comes under the general heading of 'tax morale' (see Lutmer and Singhal, 2014). It recognizes that there is more to tax related behaviour than simple economic rationality. The OECD also recognizes the value of this work (see OECD, 2013b).

Though unitary taxation provides a constructive context for change it is not without its problems and its critics (see Fleming Jr. et al, 2014; Roin, 2008; Morse, 2008). However, there are responses to the main points of critique. No system is perfect, including unitary taxation. The real issue is what set of problems would one prefer to be dealing with and when in the process of reform is it appropriate to be doing so? Unitary taxation creates an initial challenge in terms of establishing clear rules for the application of an apportionment formula (see Cobham and Lopez, 2014). But its historical record should not confuse the potential of unitary taxation. Historically, unitary taxation has been implemented within the US and Canada, where different states and provinces have sought to address problems of corporations with entities in several states and provinces (different tax jurisdictions). More than 40 US states use versions of unitary taxation, and many of these were developed separately and so vary in detail. Since 1967 the US Multistate Commission has worked to encourage uniformity among the versions. Many of the problems experienced are concerned with rendering the separately developed systems commensurate, so problems are historically cumulative. However, the broader potential of unitary taxation concerns collective agreement 
for a single agreed formula and set of implementation mechanisms. Its natural context is as a global or regional international response to the practices of MNCs. Moreover, unitary taxation is not antithetical to the use of complementary policies that address related issues for taxation (e.g. the potential for race to the bottom effects on tax rates between states). It need not stand alone. In any case, identifying problems of disjoints in actually existing systems within federalised states is not quite the appropriate context in which to consider its appeal. The primary problem is tax lost across international borders. Moreover, the major advantage of a unitary approach in an international context is that it frontloads agreement and cooperation. This is actually the reverse of the standard sceptical critique. Achieving agreement is a hurdle but it is one that is actually built into the very terms of unitary taxation as an international solution.

To be clear, a unitary tax solution cannot simply dispense with all possible problems. It cannot be divorced from the political economy in which it is embedded. It is not immune to the structural power of capital. For example, as previously noted, unitary taxation potentially recovers the sovereignty of the state vis-à-vis the corporation. However, though corporations would find it more difficult to continue to develop loopholes in relation to transfer pricing, they could lobby for concessions and exemptions in a unitary system. But any constructive change to how corporations are taxed confronts these issues of power - and corporate lobbying is not the only source of political influence or agency for political will. Awareness matters in so far as it creates scope for solutions to be worked towards and implemented, often in incremental ways. One cannot be supportive of options one does not know about, and such options cannot gain momentum unless they are supported. It is for this reason that the Tax Justice Network, typically positions its interventions in terms of cumulative momentum for constructive change (see Spencer, 2013; also, Seabrooke and Wigan, 2013; CRC, 2014). Neither the state nor the global political economy and its institutions are deterministic. Various policy trends are also significant here in two senses. The failures or limits of some policies seem likely to create additional momentum for further change, and there are also some more wide-ranging changes that are, incrementally, gaining traction.

\section{Current policy trends}

Popular focus on the problem of MNC tax has grown since the financial crisis and so politicians have more prominently acknowledged the issue. This has occurred within the G8(7) and G20, both of whom 'call on' or delegate the development of policy to the OECD. Solutions arising from the OECD, including the BEPS project, however, do not fully commit to a unitary approach. Instead there has been an amalgam of individual policy formulations. In the summer of 2014 the G-20 adopted several OECD initiatives. Specifically, members committed themselves to requiring MNCs by 2017 to engage in country by country reporting of revenue, profit and actual tax paid (see OECD, 2015). Country by country reporting provides for more comparative information and transparency regarding the real financial activity of MNCs.

Country by country reporting is a significant change (again see Eccleston et al, 2015). It improves the flow of information and thus makes it easier to identify and address tax avoidance and prosecute tax evasion. However, it does not 
address the fundamental context in which tax avoidance and evasion occur. The MNC can still be motivated to construct organizational circuits, since separate entity status and the arm's length principle still apply. The whole is still subject to resource intensive case-by-case responses that lead to problems of iterative complexity and institutional or strategic mutations as the MNC seeks to minimise tax. There is still a substantive difference in comparison to a unitary approach. Media reports of prominent politicians announcing the end of transfer pricing and of tax havens may well be premature (e.g. Aldrick, 2014b and 2014c; Mostrous, 2014).

Though reports are perhaps premature, the latest OECD BEPS action plan released in October 2015 can also be interpreted as incremental reform to a flawed process, one that represents the relative success of campaigners in maintaining pressure on states. There are also specific legal initiatives that may ultimately serve as an institutional basis for a more constructive socialisation of MNC behaviour.xii Many states now have versions of a General Anti-Avoidance Rule (GAAR) inscribed in statute. A GAAR creates a principle in law that rejects the claim that strategies that lead to avoidance are acceptable simply because they are legal. Rather the legality can be questioned because of the purpose of the strategy. A GAAR was introduced into the UK 2013 Finance Act.

Introducing a GAAR provides a way for courts to 'look through' the activity of MNCs and assess the nature and intent of strategies in context. This could allow GAAR to be used to reject strategies that are ostensibly legal and this might serve as a deterrent to MNCs. Over time this could form part of the institutional basis of a different socialisation for MNCs. However, the current GAAR in the UK combines ambiguity and a specific limiting of its coverage. The current focus of the UK GAAR is tax abuse rather than tax avoidance and the framing of the GAAR leaves open many issues regarding "reasonable" behaviour (see TUC, 2013). Furthermore the GAAR specifically excludes cases covered by double taxation treaties (HMRC, 2013: p. 7). It seems unlikely then that the current GAAR can serve as an effective legal tool to address tax avoidance. This reaffirms the significance of unitary taxation in changing the terms of debate. Moreover, the limitations of GAAR may well create further impetus for change.

This issue of restricted yet suggestive potential also applies to current UK government domestic policy regarding tax avoidance. In his 2014 Autumn Statement Chancellor Osborne announced the government would introduce a 'diverted profits tax' and this was confirmed in the 2015 budget. The process of implementation has begun for the tax year 2015-16 (HMRC, 2015b). The tax is actually in the form of a $25 \%$ levy on profits 'artificially' shifted out of the country. The tax is yet to be fully detailed as a regulatory measure (in March it remained interim, thereafter it is embryonic in the 2015 Finance Act). It has been put together quite quickly and will evolve as it is implemented and tested. However, the intention is clearly to capture some portion of the proceeds of transfer pricing. As a levy it is not a solution to transfer pricing but rather recognition of the continued significance of transfer pricing, based on separate entity status. It is an attempt to identify proceeds within organizational circuits. Identification simply replicates the problems of implementing the arm's length principle. As industry representatives have already noted, the levy will create additional complexity and legal dispute. Moreover, the government is clearly aware of this. The Treasury forecasts the tax will generate revenues of $£ 25$ million in the first year, rising to 
$£ 360$ million by $2017-2018$ and totalling $£ 1.4$ billion over the next 5 years. The sums seem large but are actually small when considered against the scale of the problem. If Google, for example, generates revenues of greater than $£ 3$ billion per annum in the UK then Google alone could account for at least $10 \%$ of the projected figures for the levy based on the current headline corporation tax rate in the UK. Clearly, the policy is already positioned for its own relative failure (even if it hits its forecasts), and is more eye-catching than effective. It does, however, serve to sustain public and political awareness of the issue of tax avoidance and this may have cumulative effects, since it creates scope for social movement momentum (within also cooperative endeavours between professionals and academics, which is the basis of the Tax Justice Network). Failure can itself be a step towards more fundamental change, since it increases the discursive weight of the alternative.

Finally, there is currently a regional unitary policy initiative. This is the EU Common Consolidated Corporate Tax Base (CCCTB). ${ }^{\text {xiv }}$ First proposed in 2001 it has been consistently opposed by the more Eurosceptic and neoliberal states, including the UK. However, the global financial crisis gave the proposal renewed momentum. Support amongst the Commission and from the EU Commissioner for Taxation resulted in a draft directive in 2011. For a directive to be adopted and to become EU law it must be unanimously endorsed. The UK and several other states remain opposed and the European Parliament expressed a variety of concerns in 2012.xv The Commission in general remains supportive and a new public forum debate on the CCCTB and on integrating the OECD BEPS initiatives began, summer 2015, and there is now an Action Plan to relaunch the CCCTB (EC, 2015). The 2011 draft directive also recognizes that the CCCTB could initially be adopted based on "enhanced cooperation". This is a mechanism that allows a group of EU members to implement a policy that may later be adopted by all. Given the public mood regarding tax avoidance, and given the continued support of the EU Tax Commissioner, there is some possibility that this may occur for the CCCTB in the near future. The momentum for change within the G-8(7) and G-20 and OECD may ultimately lead in this direction also. There then seems great scope for the adoption of a unitary system and gradual incorporation of other states within the EU and then in other regions.

\section{Conclusion}

Unitary taxation based on formula apportionment resolves an underlying problem within contemporary capitalism. It has multiple potential benefits. It prevents tax minimisation where real and effective rates diverge, and corporations are able to choose not to contribute to the reproduction of society via corporation tax. It provides grounds for a resocialisation of the firm, which may allow for more ethical behaviour. It provides one way to restore sovereignty to the state in its relations with corporations (restoring also a sense of justice and fairness to the citizen and so preventing corrosion of commitment to the state). However, a final focus on actual policy trends can be somewhat deflating in terms of presenting a case for a major change. Here, it is important to bear in mind that unitary taxation has gained traction as a policy alternative precisely because of the failures of the current system. Corporation tax is recognized as deeply problematic. The problem has definable characteristics and a clear solution. Moreover, there is significant public and political concern regarding the problem. 
The global financial crisis and its aftermath have placed a question mark against many received practices, including the tax activities of MNCs. There is then a critical context for change. For this change to occur requires awareness regarding the actual limits of the current system and the benefits of the alternative. It then requires institutional project-building. The Corporate Reform Collective (2014), the Tax Justice Network and many others are part of this process. The very existence of such organizations is a reminder that the current situation is equally a historical consequence of broader forces and specific projects (see Palan et al, 2010). Global wealth chains are not mere happenstance. As Brenner et al argue (2010: p. 339), neoliberalization 'qualitatively transformed what might be termed the 'context of context', that is, the political institutional and juridical terrain'. However, the context of context continues to develop and the future may range across a variety of possibilities. This is conditional on the future of knowledge transfer and positional persuasive argument.

\section{References}

Aldrick, P. (2014a) 'Taxman comes up short as cash-in-hand economy balloons', The Times October $17^{\text {th }}$

Aldrick, P. (2014b) 'New rules will end corporate tax abuse', The Times September $17^{\text {th }}$

Aldrick, P. (2014c) 'Osborne to stamp out 'double Irish tax avoidance', The Times September $30^{\text {th }}$

Allingham, M and Sandmo, A. (1972) 'Income tax evasion: a theoretical analysis', Journal of Public Economics 1(3-4): 323-338

Arlidge, J. and Ungoed-Thomas, J. (2013) 'Playing the tax game', The Sunday Times May $26^{\text {th }}$

Barker, A. and Houlder, V. (2014) 'Brussels probes Luxembourg over tax deal for Fiat', The Financial Times September $30^{\text {th }}$

Brenner, N., Peck, J. and Theodore, N. (2010) 'After Neoliberalization,' Globalizations 7(3): 327-345

Clausing, K. (2006) 'The role of US tax policy in offshoring', 457-486 in Collins, S and Brainard, L. eds. Brookings Trade Forum: 2005 Washington DC: Brookings Institute

Coase, R. (1988) 'The nature of the firm: Influence,' Journal of Law, Economics, and Organization 4(1): 33-47

Cobham, A. and Lopez, S. (2014) 'International distribution of the corporate tax base: Implications of different apportionment factors under unitary taxation,' Brighton: Institute of Development Studies, International Centre for Tax and Development, Working Paper 27

Colledge, B. Morgan, J and Tench, R. (2014) 'The concept(s) of trust in late modernity, the relevance of realist social theory' Journal for the Theory of Social Behaviour 44(4): 481-503

CRC, Corporate Reform Collective (2014) Fighting Corporate Abuse: Beyond Predatory Capitalism London: Pluto

Duke, S. (2014) 'Rage against the tax avoiders', The Sunday Times October $5^{\text {th }}$

EC European Commission (2012) 'Tackling tax fraud and evasion in the EU frequently asked questions', MEMO Brussels, 27 June 2012 
EC European Commission (2011) 'Proposal for a Council Directive on a Common Consolidated Corporate Tax Base', COM 2011/121/4; Brussels

EC European Commission (2014) 'State aid: Commission investigates transfer pricing arrangements on corporate taxation of Apple (Ireland) Starbucks (Netherlands) and Fiat Finance and Trade (Luxembourg)' Press Release, Brussels

EC European Commission (2015) 'Report on Competition Policy 2014', COM 2015/247; Brussels

EC European Commission (2015) 'Action Plan on Taxation' June 2015,

Eccleston, R. Kellow, A. and Carroll, P. (2015) 'G20 endorsement in post crisis global governance: more than a toothless talking shop?', British Journal of Politics \& International Relations 17(2): 298-317

Fleming Jr., J., Peroni, R. and Shay, S. (2014) 'Formula apportionment in the US International Income Tax System: Putting Lipstick on a Pig?’ Michigan Journal of International Law 36(1): 1-57

Gereffi, G., Humphreys, J. and Sturgeon, T. (2005) 'The governance of global value chains,' Review of International Political Economy 21(1): 78-104

Goodhart, C. and Ashworth, J. (2014) 'Trying to glimpse the 'grey economy" Centre for Economic Policy

Hay, C. (2013) 'Treating the symptom not the condition: crisis definition, deficit reduction and the search for a new British growth model', British Journal of Politics \& International Relations 15(1): 23-37

HCCPA (2013) 'Tax Avoidance - Google: Ninth Report of Session 2013-2014', House of Commons Committee of Public Accounts, London: HMSO

HCCPA (2012) 'HM Revenue and Customs: Annual Report and Accounts 20112012; Nineteenth Report of Session 2012-2013', House of Commons Committee of Public Accounts, London: HMSO

Henry, J. (2012) 'The price of offshore revisited: new estimates for missing global private wealth, income inequality and lost taxes' Tax Justice Network,

HMRC (2013) 'HMRC's GAAR Guidance' London: HMRC

HMRC (2015a) International Manual London: HMRC

HMRC (2015b) 'Diverted profits tax: Interim guidance', London: HMRC

IBE (2013) 'Attitudes of the British Public to Business Ethics: 10 year trends and 2013 findings', Business Ethics Briefing 35: 1-7

Kleinbard, E. (2011) 'Stateless income', Florida Tax Review 11(9): 699-774

Kleinbard, E. (2013) 'Through a Latte Darkly: Starbuck's stateless income planning', Tax Notes June 1515-1535

Kobetsky, M (2011) International Taxation of Permanent Establishments Cambridge: Cambridge University Press

Levin, C. Chairman (2013) 'Offshore profit shifting and the US tax code - Part 2 (Apple inc.)', Hearing before the subcommittee on investigations of the Committee on Homeland Security and Governmental Affairs, United States Senate, One Hundred Thirteenth Congress, First Session, May $21^{\text {st }}$ Washington DC: US Government Printing Office; available: http://www.gpo.gov/fdsys/pkg/CHRG-113shrg81657/pdf/CHRG113shrg81657.pdf

Lawson, T. (2015) 'The modern corporation: the site of a mechanism (of global social change) that is out-of-control?', in M. Archer editor Social Morphogenesis New York: Springer 
Luttmer, E. and Singhal M. (2014) 'Tax Morale' Journal of Economic Perspectives 28(4): 149-168

Morgan J. (2011) 'Ethos and reform of finance systems: a tentative argument', Real World Economics Review 58: 89-94

Morgan, J. editor (2016) What is neoclassical economics? Debating the origins meaning and significance London: Routledge

Morse, S. (2010) 'Revisiting global formulary apportionment,' Virginia Tax Review 29: 593-644

Mostrous, A. (2014) 'Tax havens 'will be wiped out in 5 years", The Times October $31^{\text {st }}$

Murphy, R. (2014) 'The end of transfer pricing is nigh... Or maybe not', Tax Notes International 73(1): 19-22

Neilson, J., Pritchard, B. and Yeung, H. (2014) 'Global value chains and global production networks in the changing international political economy: an introduction,' Review of International Political Economy 21(1): 1-8

OECD (2015) 'Action 13: Country by country reporting implementation package', Paris: OECD

OECD (2014) Model Tax Convention on Income and on Capital, ninth revision, Paris: OECD

OECD (2013) 'Action plan on base erosion and profit shifting', Paris: OECD

OECD (2013b) 'Tax and development: What drives tax morale?' Paris: OECD

OECD (2010) OECD Transfer Pricing Guidelines For Multinational Organizations and Tax Administrations Paris: OECD

OECD (2002/2008) 'Transfer pricing: Keeping it at arm's length,' OECD Observer 230 (corrected, 2008)

OECD (2001) 'Principles of good tax administration - practice note', Paris: OECD

OECD (1998) Harmful tax competition: an emerging global issue Paris: OECD

Palan, R. (2002) 'Tax havens and the commercialization of state sovereignty,' International Organization 56(1): 151-76

Palan, R., Murphy, R. and Chavagneux, C. (2010) Tax Havens New York: Cornell University Press

Palan, R. and Wigan, D. (2014) 'Herding cats and taming tax havens: The US strategy of "not in my backyard", Global Policy 5(3): 334-343

Peck, J. (2013) 'Explaining (with) neoliberalism,' Territory, Politics, Governance 1(2): $132-157$

Picciotto, S. (2014) 'From independent entity back to the unitary principle', Tax Notes International 73(1): 13-18

Picciotto, S. (2012) 'Towards Unitary Taxation,' Tax Justice Network

Picciotto, S. (2011) Regulating Global Corporate Capitalism Cambridge: Cambridge University Press

Picciotto, S. (1992) International Business Taxation London: Weidenfeld and Nicolson

Quentin, D. (2014) 'Risk-mining the public exchequer: reflecting the realities of tax risk in the theory of tax avoidance,'

Reuven, S. Avi-Yonah (2014) 'Back from the dead: reviving transfer pricing enforcement', Tax Notes International 73(1): 10-12

Roin, J. (2008) 'Can the income tax be saved? The promise and pitfalls of unitary formulary apportionment,' Tax Law Review 61(3): 169-214 
Seabrooke, L. and Wigan, D. (2014) 'Global wealth chains in the international political economy', Review of International Political Economy 21(1): 257263

Seabrooke, L. and Wigan, D. (2013) 'Emergent entrepreneurs in transnational advocacy networks: Professional mobilization in the fight for global tax justice,' GR:EEN Working Paper 41: Centre for the Study of Globalization and Regionalization, University of Warwick

Sharman, J. (2010) 'Offshore and the new international political economy,' Review of International Political Economy 17(1): 1-19

Shaxson, N. (2011) Treasure Islands: Uncovering the damage of offshore banking and tax havens Palgrave Macmillan

Sikka, P. (2015) 'No accounting for tax avoidance,' Political Quarterly 86(3): 427433

Sikka, P. and Willmott, H. (2010) 'The dark side of transfer pricing: Its role in tax avoidance and wealth retentiveness', Critical Perspectives on Accounting 21: 342-356

Sikka, P. and Willmott, H. (2013) 'The tax avoidance industry: accountancy firms on the make', Critical Perspectives on International Business 9(4): 415-443

Spencer, D. (2013) 'The Helsinki Seminar on Transfer Pricing,' Tax Justice Focus $7(3): 1-2$

Sullivan, M. (2008) 'US multinationals shifting profits out of the United States', Tax Notes, 136 (37): 1-9

Thompson, H. (2013) 'UK debt in comparative perspective: The pernicious legacy of financial sector debt', British Journal of Politics \& International Relations 15(3): 476-492

TUC (2013) 'The deficiencies in the General Anti-Abuse Rule', TUC

Ungoed-Thomas, J and Duke, S. (2013) 'My 100,000 emails that prove Goggle has lied', The Sunday Times May 19th

UNODC (2014) 'Money Laundering and Globalization, United Nations Office on Drugs and Crime', United Nations Office on Drugs and Crime

Waterfield, B (2015) 'McDonald's inquiry sprouts in Brussels', The Times, 6 May. Available at: http://www.thetimes.co.uk/tto/business/industries/retailing/article443 1453.ece (accessed December 31st)

Woodward, R. (2004) 'The Organization for Economic Cooperation and Development', New Political Economy 9(1): 113-127

Ylonen M. and Teivainen, T. (2015) 'Politics of intra-firm trade: Corporate price planning and the double role of the arm's length principle,' Paper: Should the Nation State Compete? Workshop City University $25^{\text {th }} / 26^{\text {th }}$ June

Zoromé, A. (2007) 'Concept of Offshore Financial Centers: In Search of an Operational Definition', IMF Working Paper 07/87

Zucman, G. (2014) 'Taxing across borders: Tracking personal wealth and corporate profits', Journal of Economic Perspectives 28(4): 121-148

\footnotetext{
i Note, the use of non-economic does not imply a reductive 'economism' (see Morgan, editor, 2016). It merely suggests it is possible to differentiate between having an actual economic purpose and having what is essentially merely a tax purpose.

ii The OECD guidelines identify 5 methods to assess transfer pricing. These divide into three preferred "traditional" transaction methods and two transactional profit methods (OECD, 2010).
} 
iii Intra-firm transactions are supposed to be planned and administered, whilst markets are not. The very basis of efficiency and of price determination would seem to imply the prices would likely deviate between the two. One can then ask what real role does the arm's length principle play? See Ylonen and Teivainen, 2015.

iv For example, recent issues surround 'Advance Pricing Agreements.' The corporation negotiates with a tax authority to agree a transfer pricing methodology to be applied to a designated set of transactions for a given period (then termed 'covered transactions').

$v$ The existence of a loss may be beneficial since in most tax authorities it creates the potential for future tax relief (a tax credit). The existence of some profit may be beneficial since it allows the firm to pay some tax in the locality, facilitating the claim that taxes are paid and the firm is both compliant and a responsible corporate citizen.

vi The issue for Ireland is complex, creating numerous genuine economic problems. Apple employs over 1,500 people in Ireland. There are more than 1,000 MNCs located in Ireland employing in total more than 150,000 and this constitutes the highest proportion of total employment in any OECD country. However, Senator McCain put the matter starkly in his opening statement to the US Senate Subcommittee: "Apple contends that none of its subsidiaries in Ireland reduce its U.S. tax liability by one cent. This statement is demonstrably false." (McCain in Levin 2013: p. 9; for Apple's rejoinder see the testimonies of Timothy Cook CEO and other Apple representatives in Levin, 2013)

vii "According to Article 107(1) of the Treaty on the Functioning of the European Union (TFEU), state aid, which affects trade between Member States and threatens to distort competition by favouring certain undertakings is in principle incompatible with the EU Single Market. Selective tax advantages may amount to state aid." (EC, 2014).

viii Low commitment capitalism involves the opportunity for a corporation to position itself in ways that maximise its capacity to 'free ride' on society through a number of strategies made possible by neoliberalism (see Neilson et al., 2014 for sources).

${ }^{\text {ix }}$ However, the issue of the relation of tax to fiscal policy depends also on how one conceives money and money creation - and this is a matter of significant dispute based on the work of Knapp, Innes, Ingham, Wray and many others.

$x$ One should also not neglect the more sinister consequences of our current tax system. According to the Tax Justice Network, tax havens host accumulated wealth estimated at more than US\$21 trillion (Henry, 2012). Access to and use of these havens is created by prominent financial organizations. The existence of such havens then also provides a location for wealth to be fraudulently siphoned away from states and concealed, and for organized crime to launder money and store wealth. The United Nations Office on Drugs and Crime (UNODC) estimates that between US $\$ 800$ billion and US $\$ 2$ trillion per annum is laundered via tax havens (UNODC, 2014).

xi Goodhart and Ashworth (2014) estimate that the UK gray economy has grown by $4 \%$ since the end of 2007.

xii This statement was made in the context of further controversy in 2013 regarding the testimony to the UK Parliamentary Affairs Committee of Matt Brittin, Google's vice-president for northern and central Europe. Brittin had stated to the Committee that UK Google staff did not complete ('close') the sale of advertising and that this was done in Ireland. A former Google employee Barney Jones then came forward with a dossier of more than 100,000 e-mails that challenged this claim, though it hinges on exactly what 'close' means (Ungoed-Thomas and Duke, 2013).

xiii An additional initiative worth consideration is the US Foreign Account Tax Compliant Act (FATCA) 2010. This targets tax abuse indirectly by placing a pressure on intermediaries operative in US territories to sanction third parties; it thus extends US influence to non-US spaces and actors. The Act also encourages other OECD states to emulate its position, so the approach is unilateral but directed at multilateral transformation (see Palan and Wigan, 2014) See also Richard Murphy's UK Fair Tax Mark initiative. http://www.fairtaxmark.net/ftm15-historic-day-fair-tax-mark/

xiv It is based on the following formula, the algebra alters slightly for the 2011 directive (EC, 2011a: Article 86, p. 49):

$$
\text { Share A }=\left(\frac{1}{3} \frac{\text { Sales }^{\mathrm{A}}}{\text { Sales }^{\text {Group }}}+\frac{1}{3}\left(\frac{1}{2} \frac{\text { Payroll }^{\mathrm{A}}}{\text { Payroll }^{\text {Group }}}+\frac{1}{2} \frac{\text { No of employees }^{\mathrm{A}}}{\text { No of employees }^{\text {Group }}}\right)+\frac{1}{3} \frac{\text { Assets }^{\mathrm{A}}}{\text { Assets }^{\text {Group }}}\right) * \text { Con'd Tax Base }^{\text {en }^{\prime}}
$$

xv Notably that adoption creates transitional risks and uncertainty for individual states and that the policy may lead to pressure for harmonisation of corporation tax, which some of the states who consider tax to be a part of a competitive environment oppose. 